\title{
The Influence of Spatial Flexibility to improve Sustainability of Interior Design by Using Smart Technology (Case study -Future Smart home in Iraq)
}

\author{
Ibtisam Abdulelah Mohammed Al Khafaji ${ }^{1}$ and Raz Kamaran ${ }^{2}$
}

\begin{abstract}
Technological progress is an endless accelerating phenomenon. It becomes a major aspect of our wellbeing and influences our everyday life as well as our use of architectural spaces. A professional career in Interior Design is more challenging today than ever. It combines the creative, the aesthetic, the innovative, and the practical to create the important stages upon which people live their lives. This pragmatic approach found a considerable positive impact on enhancing overall building flexibility and sustainability by using smart technology. Literatures displayed that both terms flexibility and sustainability -are used almost to the same extent. In general, developing space flexibility is one of the main ways to achieve Sustainability to ensure efficient space utilization. The objectives of this research is to explain how smart interior design can improve spatial flexibility of inner spaces and to evaluate whether flexibility had a positive impacts toward sustainability (case study: Iraqi houses). A literature review in the disciplines of, smart home technology, spatial flexibility and Interior design sustainability have been done, then we used virtual reality methods and self -assessment practical tools to improve better understanding and to test hypothesis. Results explained that smart design improve spatial flexibility by and ensure efficient space utilization (sustainable inner spaces).
\end{abstract}

Keywords: Flexibility, Sustainability, Smart Technology, Smart Interior Design, Smart Homes

\section{Introduction}

The last few decades have seen unprecedented social, technological and economic changes, and innovation is becoming critical to many fields includes architecture. Buildings need a flexible structure and flexible spatial configuration in order to meet rapidly changing demands [1]. The words ' Flexibility and ' Sustainability ' have become more prominent, Flexible Architecture has become more widespread in the late 1960s, and the phrase Sustainable Architecture ' has also become more common since 1987 [6]. The Notion of flexible, adaptive, changeable building are not new, it has been presented for centuries in building traditions of many different culture around the world. "Flexible means architecture that responds to change, as Branko said that we live in times of rapid changes where advances in technologies are frequent, the expectations of users are shifting, and demands on environments are intense [4]. Furthermore "A sustainable building is not one that must last forever, but one that can easily adapt to change. If a building doesn ${ }^{\text {ee }}$ support change, you have only an illusion of sustainability [9]. Smart design, flexibility and sustainability will be explained in the following pages to specify research problem -aim -methods. 


\subsection{Sustainable interior design}

The most quoted definition of Sustainable Development is: "Development that meets the needs of the present without compromising the ability of future generations to meet their own needs" as presented by the UN commission on Environment and Development (1987). Sustainable Interior Design can be defined as design that sensibly addresses the impact of all its functions and elements on the global environment. Environmental responsibility of the interior design profession has been interpreted as comprising three issues: Ecological effectiveness, Economic consequences and social system "s considerations that related to the inner space quality parameters and their influence on the occupants"e psychological and physical comfort. In general, one of the most important ways to achieve sustainability is to develop the flexibility and adaptability of systems [14]. Newman, defined flexibility as one of the sustainability fundamentals principles as: capacity, fitness, resilience, diversity, and balance [15].

\subsection{Smart Technology for Flexibility and Sustainability}

The biggest challenge faced by architects is the users of buildings, their needs, and their wishes change rapidly during the time. Buildings require a flexible physical, spatial, and cultural structure to respond to the changes. Flexibility means the ability to change spaces without changing physical configuration of a building [20].

The basic concept of Spatial Flexibility is that spaces should not be dominated by determinism. Architects should design the space to maximize the possibilities of change, so that the space could be more adaptable to maintain valuable all through the life span [12]. Hence, designers possessing the tools for integrating smart solutions into interior design solutions which have the capability of learning and even anticipating occupantse needs and preferences, thereby increasing lifestyle comfort and flexibility, raising energy efficiency, and reducing costs that lead to achieving a more sustainable interior design [10]. Both the Certification Policy Manual of the Leadership in Energy and Environmental Design (LEED) and the Technical Manual of the Building Research Establishment"s Environmental Assessment Method include smart design solutions as part of evaluating a buildinge"s sustainability. Therefore, interior designers should understand the impact of applying smart solutions to sustainable interior design. Interior designers may consider this combination to be an ideal solution that reflects a concern for both natural ecological systems and building occupantse technological lifestyle [19]. Smart interior design is the future of design. It depends on the integration of varied sensors, devices, and computing into building systems through appropriate networking and operation platforms, as well as the innovative utilization of material, light fixtures, and equipment that support the expansion of sustainability practices. Smart materials and furnishings dramatically reduce the need for different design components, sustaining the interior mood for longer periods. This trend also enhances the environmental and economic efficiency of interior design in addition to improving occupant wellbeing and productivity [20]. Smart interior design can be defined as using techniques to increase the flexibility of building compartments to reduce the amount of built areas while maintaining the required requirements. These techniques improve the flexibility and adaptability of buildings by increasing the number of possible uses of building 
compartments over time. These extra features eliminate any need for additional compartments and allow minimizing the area of premises while retaining or perhaps even increasing functionality and possibly comfort. Also Smart Technology improves space efficiency of any building by increasing possible and actual number of users in the same area and increase the amount of time-space is used. A high level of space utilization because the space is used for the maximum possible amount of time [20]. Smart interior design solutions should incorporate flexible structures that can accommodate smart design facilities. In particular, solutions should maintain responsive cabling design, an open space with movable or demountable partitions, raised floors, suspended ceilings, and mechanical floors to permit connection between different design elements across a single infrastructure. Finally Smart design concepts can therefore be considered highly interrelated with sustainable design in support of creating a new environment that meets present needs without compromising future generations [10]. Smart design concepts can be considered highly interrelated with sustainable design in support of creating a new environment that meets present needs without compromising future generations. Hence, designers possessing the tools for on-going technology expansion realize that integrating smart solutions into interior design will significantly boost environmental, economic, and socio-cultural sustainability [4]. Smart building can decide on time, the most effective ways to create an environment and sustainable responsive, to raise the efficiency of its occupants with the lowest possible costs throughout the life span of the building. [8]

\subsection{Research Motivation / Research Problem, Aims and Methodology}

There are good reasons to believe that traditional concepts of housing may no longer be adequate due to a series of contextual and lifestyle changes. As an example, since daily activities become more flexible (e. g. people can work in different location of a house), the space should support this flexibility and lets user adjust privacy of the space according to his/her activity.

Hence, separated functional rooms with fixed boundaries seem to be no longer appealing. Research definitions of Sustainable inner spaces is: Functional efficiency of spaces that can be created by increasing possible and actual number of users in the same area and increase the amount of time-space is used. While spatial flexibility means a quality of inner spaces which have the capacity to response quickly to the changes that happened in spaces, and have the capacity of re-configure spaces (layout-organization quantity -size )to enhance changing of space activities (space occupancy) without changing physical forms. The biggest challenge faced by architects is the users of buildings, their needs, and their wishes change rapidly during the time. Buildings therefore require a flexible physical, spatial and cultural structure to respond to changes and meet rapidly changing demands. In the case of Smart Homes, the spaces can accommodate multiple activity types and are multifunctional. Interior systems are interactive, responsive, and able to create different contexts for different activities. Therefore, new spatial organization and new types of combination of technology and space are expected to match space with technological changes and lifestyle changes of the inhabitants. From literature review, we can specified:

-Research problem:There is No clear theoretical concepts and practical tools that can be used to explain how smart technology can improve spatial flexibility then enhanced 
sustainability of interior design in local dimensions ( Iraqi houses).

- Research aim: Clarifying this relation, in simple words is to determine how designers can improve flexibility then enhancing sustainability by using smart design.

-Hypothesis: We suppose that: Using Smart Interconnected spatial devices improve Spatial

Flexibility then enhance Sustainability of Inner spaces in Iraqi houses

Methodology: From literature review in the disciplines of, smart home technology, spatial flexibility and Interior design sustainability we formed a theoretical structural , then we used virtual reality methods and self -assessment practical tools for applying related variables. we chose a sample of 30 persons(all are Iraqi young persons ) and five international projects which applied smart technology inside privet residential

Results explained that smart design improve spatial flexibility by ......... and ensure efficient space utilization (sustainable inner spaces) $\ldots \ldots \ldots \ldots \ldots \ldots \ldots \ldots \ldots$

\section{Conceptual Structure}

This section aims to establish a conceptual structure that can be used to describe relationship between spatial flexibility and Sustainability of inner spaces with the use of smart design technologies. Three factors can be mentioned here:

\subsection{Factors related to sustainability}

According to (Newman, 1999) the Main standards of sustainability are Capacity, Fitness, Resilience, Diversity, and Balance, Scalability and Adaptation. The possibility of multiple use and saving on space and energy, compacted the building for more than one function with less size [2]. While Erfaneh Allameh [7] explained the possible contributions of smart home concepts and developments to by (table 1)

Table (1) Factors related to sustainability1Factors related to sustainability -by researchers

\begin{tabular}{|c|c|c|}
\hline $\begin{array}{l}\text { Factors related to } \\
\text { sustainability1Factors } \\
\text { related } \\
\text { to sustainability }\end{array}$ & Description & References \\
\hline space saving & $\begin{array}{l}\text { Reducing the need of distinct physical spaces for home office because } \\
\text { of the integration between work activities with life } \\
\text { Reducing the number of devices in a house, } \\
\text { Mixing several zones with each other and blurring the boundaries by } \\
\text { multitasking } \\
\text { Use of virtual space instead of physical space by several tele-activities, } \\
\text { Use of flexible and multifunctional devices and furniture } \\
\text { Improvement of the flexibility of spaces, }\end{array}$ & $\begin{array}{l}\text { Erfaneh } \\
\text { Allameh } \\
\text { and others } \\
2018\end{array}$ \\
\hline
\end{tabular}

\subsection{Factors related to smart design}

\subsubsection{Principles of smart design}

One of the principle challenges in smart architecture is how to construct systems that would provide enough variety to keep users engaged, four basic principle explained natural relation between users and spaces [4], (table 2). 
Table (2) Principles of smart design -by researchers

\begin{tabular}{|l|l|l|}
\hline $\begin{array}{l}\text { Principles of } \\
\text { smart design }\end{array}$ & Description & References \\
\hline Diversity & $\begin{array}{l}\text { Designer and planner over the past century were enamored with clinical zoning, } \\
\text { under such zoning, uses were highly separated and segregated. In recent years, } \\
\text { designers have called for a re-consideration of a distinct zooning as a *mosaic of } \\
\text { activities* }\end{array}$ & Branko \\
\hline -Agility & $\begin{array}{l}\text { In buildings that have fixed and static structure, not easily modified or adjusted } \\
\text { despite the fact that needs and uses may and do change over time. the result of } \\
\text { this approach is that such buildings often cannot readily adapt to changing } \\
\text { demands. Buildings cannot easily be reconfigured, expanded, or contracted as } \\
\text { activities shift. Agility calls for thinking (designing and planning) and acting } \\
\text { (constructing) that is far more open, responsive to needs, responsible to society, } \\
\text { and system -oriented. Agile architecture encourages great mutability and } \\
\text { adjustability across all realms of the building }\end{array}$ \\
\hline $\begin{array}{l}\text { Reactive } \\
\text { architecture }\end{array}$ & $\begin{array}{l}\text { Reactive or Responsive architecture means subtle technology as a networked } \\
\text { structure that senses action within a field of attention and responds dynamically } \\
\text { with programmed and design logic }\end{array}$ \\
\hline $\begin{array}{l}\text { 4-Interactive } \\
\text { Architecture }\end{array}$ & $\begin{array}{l}\text { The primary goal of responsive, adaptive architecture is to imbue building with } \\
\text { the capacity to interact with the environment and their users in an engaging way. } \\
\text { The user should have an effect on the system s behavior or its outcome and } \\
\text { how that behavior or outcome is computed }\end{array}$ \\
\hline
\end{tabular}

\subsubsection{Smart technologies inside smart home}

A brief description of the most influential smart technologies on the spatial design of houses is given in (table 3). [14], [11]

Table (3) Smart technologies inside smart home

\begin{tabular}{|c|c|c|}
\hline $\begin{array}{l}\text { Smart } \\
\text { technologies } \\
\text { inside smart } \\
\text { home }\end{array}$ & Description & references \\
\hline \multirow[t]{4}{*}{$\begin{array}{l}\text { Technical } \\
\text { components }\end{array}$} & $\begin{array}{l}\text { Sensors and Actuators: sensors and actuators are responsible for performing } \\
\text { the five basic functions of building automation (switching, positioning, } \\
\text { indications, counting and measuring ). }\end{array}$ & \multirow[t]{3}{*}{$\begin{array}{l}\text { Maad Bali } \\
2018\end{array}$} \\
\hline & $\begin{array}{l}\text { Automation Equipment: is responsible for processing functions (monitoring, } \\
\text { controlling, regulating, and optimizing ) }\end{array}$ & \\
\hline & $\begin{array}{l}\text { Management and Operating Equipment:it is responsible for the operating } \\
\text { and management functions }\end{array}$ & \\
\hline & $\begin{array}{l}\text { Data Interface Units:In all situations where two or more networks based on } \\
\text { different communication systems have to be connected to each other. }\end{array}$ & \\
\hline \multirow[t]{3}{*}{$\begin{array}{l}\text { Spatial } \\
\text { interconnected } \\
\text { devices }\end{array}$} & $\begin{array}{l}\text { Smart kitchen table is an interactive table which can be used as a } \\
\text { multipurpose space, making the kitchen more social and convenient while } \\
\text { improving space saving. Users can have more comfortable and flexible } \\
\text { cooking experience, eating, entertaining, working and enjoying food while } \\
\text { reducing energy consumption and optimizing waste management. }\end{array}$ & \multirow[t]{3}{*}{$\begin{array}{l}\text { Heidari } \\
\text { Jozam, } \\
2016\end{array}$} \\
\hline & $\begin{array}{l}\text { A smart wall with "hidden" equipment, such as cameras and sensors } \\
\text { combines the concept of both TV and computer together. This wall's goal is } \\
\text { to serve the following attributes-A changeable scenery system, Interactive } \\
\text { electronic surfaces on the wall, Tele- activities, such as tele-educating, tele- } \\
\text { caretaking, e- meetings, and tele-team working. }\end{array}$ & \\
\hline & A smart floor can detect the location and behavior of the inhabitants in a room & \\
\hline
\end{tabular}




\begin{tabular}{|l|l|}
\hline $\begin{array}{l}\text { Smart furniture has a different user interface and interaction style from the } \\
\text { current furniture and computers, the common features of smart furniture } \\
\text { can be introduced as: Flexible, moveable, Intelligent (e. g. a smart mirror can } \\
\text { recognize the user and show personalized information or a smart bed can } \\
\text { monitor conditions of the user body and adjust the environmental } \\
\text { conditions accordingly), Responsive (e. g. a smart light is dimming when a } \\
\text { user is not close to it or becomes brighter and more targeted when the user } \\
\text { is studying or cooking), Interactive, touch screen surfaces, Multifunctional. }\end{array}$ \\
\hline $\begin{array}{l}\text { Smart boundaries with adjustable transparency are smart glasses that offer } \\
\text { switchable opaque on demand. They give the user the ability to "tune" the } \\
\text { amount of light, sun glare or view when required. Accordingly, smart } \\
\text { partitions can provide different contextual areas with controlling } \\
\text { environmental conditions such as light, temperature, view, and sound. }\end{array}$ \\
\hline
\end{tabular}

\subsection{Factors related to spatial flexibility}

\subsubsection{Principles}

Architecture in our present time should be more flexible, agile adaptable and elastic. Six principles can respond to the users ${ }^{\text {ee }}$ needs and desires to re-imagine and reconfigure the space as they whishes in real time shown in (table 4). [19], [4]

Table (4) Principles of spatial flexibility -by researchers

\begin{tabular}{|c|c|c|}
\hline $\begin{array}{l}\text { Principles } \\
\text { spatial } \\
\text { flexibility }\end{array}$ & Description & references \\
\hline Loose-Fit & $\begin{array}{l}\text { the idea of a loose -fit building or Duffle coat strategy suggests that designers } \\
\text { should avoid too tight a match between activities and spaces and create some } \\
\text { (slack) which may be valuable when activities change }\end{array}$ & \multirow{2}{*}{$\begin{array}{l}\text { William } \\
\text { Fawcett } \\
2016\end{array}$} \\
\hline \begin{tabular}{|l|} 
Activity -space \\
tolerance
\end{tabular} & $\begin{array}{l}\text { :-Lose - fit flexibility is enhanced when there is a high level of tolerance } \\
\text { between the attributes of activities and spaces, withe activity-space tolerance, it } \\
\text { does not matter if the spaces are not identical in size ( }\end{array}$ & \\
\hline Agility & $\begin{array}{l}\text { Instead of user adapting to space, agility means that space to be designed with } \\
\text { enough flexibility to adapt to users }{ }^{\text {e }} \text { needs and desires. The sense of control } \\
\text { over the space psychologically empowers the users whereas, conversely, not } \\
\text { being able to change the surroundings would result in stress, distress and } \\
\text { discomfort }\end{array}$ & \\
\hline Responsive & $\begin{array}{l}\text { The skin, structure and infill should be equipped with enough elasticity to be } \\
\text { able to respond to environmental conditions, adjust to userse needs, and } \\
\text { generate energy from renewable sources to which the building is not neutral } \\
\text { and stand-alone relative to its users and context }\end{array}$ & \\
\hline Resonant & $\begin{array}{l}\text { Open buildings should be designed with a meaningful balance between interior } \\
\text { and exterior, between spatial, functional and aesthetic aspects. Focusing on the } \\
\text { reconfigurable of } * \text { infill* should not overshadows the potential of dynamism, } \\
\text { customization, and energy generation in the design of an exterior shell }\end{array}$ & \\
\hline Resilient & $\begin{array}{l}\text { The building systems should be designed with the capacity to cope with future } \\
\text { changes with minimum demolition, cost, and waste and with maximum } \\
\text { robustness, mutability and efficiency }\end{array}$ & \\
\hline
\end{tabular}

\subsubsection{Space organization}

Spatial flexibility realizes the user's needs and desire to make changes in the compositions and arrangements of space. Spatial flexibility is responsive to momentary changes in the needs of users, which is why it accommodates short-term changes and 
permits the unfolding of different functions within a singular space, therefore it considers long -term change in spatial needs. Variables are shown in (table 5 ) . [4], [12]

Table (5) Space organization -by researchers

\begin{tabular}{|l|l|l|}
\hline $\begin{array}{l}\text { Space } \\
\text { organization }\end{array}$ & Description & References \\
\hline $\begin{array}{l}\text { Principles for } \\
\text { Space } \\
\text { Organization } \\
\text { third dimension is dismissed, volume, or (xyz coordinates) }\end{array}$ & $\begin{array}{l}\text { Flow :It is important to consider the flow of spaces to determine which spaces } \\
\text { are shared and to pay attention to the circulation between these spaces }\end{array}$ & $\begin{array}{l}\text { Order: In the flexible plan, there is no defining hierarchical order between the } \\
\text { spaces. In spatial flexibility the focus is on sequencing the spaces in away that } \\
\text { allows for differing compositional arrangements. In the flexible plan, there is no } \\
\text { defining hierarchical order between the spaces. In spatial flexibility the focus is } \\
\text { on sequencing the spaces in a way that allows for differing compositional } \\
\text { arrangements }\end{array}$ \\
\hline $\begin{array}{lll}\text { Spatial } \\
\text { elements }\end{array}$ & $\begin{array}{l}\text { The alterable spaces are divided with the use of sliding, folding, retracting, } \\
\text { collapsing and movable walls that can be reconfigured and rearranged according } \\
\text { to the user ,swishes }\end{array}$ & \\
\hline $\begin{array}{l}\text { Types } \\
\text { spaces }\end{array}$ & $\begin{array}{l}\text { of In these systems, the plane should be divided into space that change and do not } \\
\text { change }\end{array}$ & \\
\hline $\begin{array}{l}\text { factors of } \\
\text { space }\end{array}$ & $\begin{array}{l}\text { To analyze the factors of a space reacting with function could provide strategies } \\
\text { to facilitate the possibility of change. Function has certain relation with three } \\
\text { factors of a space: size, shape and quality. And for the function occurs in a series } \\
\text { of spaces, linkage between them plays an important role. }\end{array}$ & 2005 \\
\hline
\end{tabular}

\subsubsection{Levels of flexibility}

For measuring flexibility, time or duration of adaptation process can be used as the key variables. The duration between the (end-date of existing use to start -date of changed use will determine the level of flexibility. Variables shown in table (6). [5]

Table (6) Levels of flexibility -by researchers

\begin{tabular}{|c|c|c|}
\hline Level 1 of flexibility & Define Duration & \multirow{2}{*}{ Reference } \\
\hline 1 & Very short overnight or weekend & \\
& Up to 2 weeks & \\
& 2012 \\
\hline 3 & Up to 3 months & \\
\hline 4 & Up to 6 months & \\
\hline 5 & Up to 1year & \\
\hline
\end{tabular}

\subsubsection{Means to reach flexibility}

Variables shown in table( 7 ). [8], [4], [6]

Table (7) Means to reach flexibility -by researchers

\begin{tabular}{|l|l|l|}
\hline Means & Description & Reference \\
\hline Adapt & $\begin{array}{l}\text { Means designing building to adjust to different functions, users, and climates Faiza } \\
\text { change building must be able to respond to future changes in occupation needs, } \\
\text { external factors and user requirements. }\end{array}$ & $\begin{array}{l}\text { Nakib } \\
2010\end{array}$ \\
\hline Transform & $\begin{array}{l}\text { means the capacity of building to change shape, space, form or appearance by the } \\
\text { physical alteration of their structure, skin or internal surfaces }\end{array}$ & \\
\hline Moving & means converting the room into an inside /outside space & \\
\hline
\end{tabular}




\begin{tabular}{|c|c|c|}
\hline \begin{tabular}{|l|} 
Multi- \\
functionality
\end{tabular} & $\begin{array}{l}\text { refers to physical components of a space, which allow it to be used in different } \\
\text { ways and for a set of known functions. ( }\end{array}$ & \\
\hline \begin{tabular}{|l|} 
Trans- \\
functionality
\end{tabular} & $\begin{array}{l}\text { Trans-functionality is made of physical components that support the creation of } \\
\text { new undetermined and unpredictable functions according to the free users } \\
\text { experience and consumption of the space. }\end{array}$ & \\
\hline \begin{tabular}{|l|} 
Neutral \\
Functionality
\end{tabular} & $\begin{array}{l}\text { Room without labels that do not have a specific use... this means that the later } \\
\text { can take on other uses (i. e. work spaces, sitting in the bedroom) }\end{array}$ & \\
\hline Mobility & $\begin{array}{l}\text { refers to the built-in possibilities to move, rearrange, take away, or add elements } \\
\text { within an existing main structure. For that, partitions should be demountable, } \\
\text { movable, reusable and recyclable. }\end{array}$ & \\
\hline Interact & $\begin{array}{l}\text { include buildings that respond to users requirements in automatic or intuitive } \\
\text { ways }\end{array}$ & $\begin{array}{l}\text { Branko, } \\
2015\end{array}$ \\
\hline \begin{tabular}{|l|} 
Partition \\
ability
\end{tabular} & $\begin{array}{l}\text { is the possibility of splitting up, rearranging or combining different spatial units } \\
\text { in a simple way." }\end{array}$ & $\begin{array}{l}\text { H. Estaji } \\
2017\end{array}$ \\
\hline \begin{tabular}{|l|} 
Convertibility \\
Convertibility
\end{tabular} & : Allowing for changes in use (economically, legally, technically) & \\
\hline \begin{tabular}{|l|} 
Rearrange- \\
Ability
\end{tabular} & Change the layout of spaces. & \\
\hline Responsive & Smart, Intelligent, Automated & \\
\hline Scalability & Change of size & \\
\hline Refittability & Change of performance. & \\
\hline
\end{tabular}

\section{Case study /Practical method -Results and Conclusion}

In our research, we aim to investigate the impact of smart design to improve spatial flexibility of Inner spaces and to evaluate how future interior space could be organized more efficient by saving spaces then enhance sustainability. Different research tools, which can be applied in experimental research on smart, while living labs are introduced as the most common in using facilities, virtual reality methods are argued as another assessment research tool in smart home researches; especially in researches that need high levels of experimental control. In this regard, we need relatively a large sample size with various characteristic, who can experience living in a smart home and then express how the inner spaces and the home conditions would change empirical experiment in living labs) needs a lot of time, infrastructure, and cost, which cannot be provided in this research. Hence, we choose to apply a $3 \mathrm{~d}$ VR $(3 \mathrm{~d}$ responsive smart home. Independent variables as (occupant interactions) and spatial smart technology are going to be chose and dependent variables are (levels of flexibility and re-organization of spaces). we have test variable by using questionnaire (self -assessment practical tools ) has been developed to improve understanding of the requirements and elements of architecture flexibility, based on best practices and standards in business process architecture, design and quality management. In this practical tools, a series of questions to identify to what extent your architectural flexibility initiative is complete in comparison to the requirements set in standard. To facilitate answering the questions, there is a space in front of each question to enter a score on a scale of (1) to (5).

Read the question and rate it with the following in front of mind:

In my belief,

The answer to this question is clearly defined

A score of (1) would mean that the answer is not clear at all, where a (5) would mean the 
answer is crystal clear and defined. When the question is not applicable or you don't want to answer it, you can skip it without affecting your score and leave it empty. After you have responded to all the appropriate statements in each section, compute your average score for that section, using the formula provided, and around to the nearest tenth. [3]

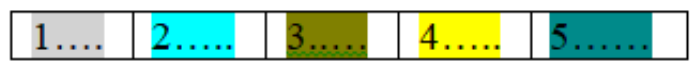

\section{Imagine that you have smart home then answer the following questions}

Table (8) Self -assessment practical tools - by researcher

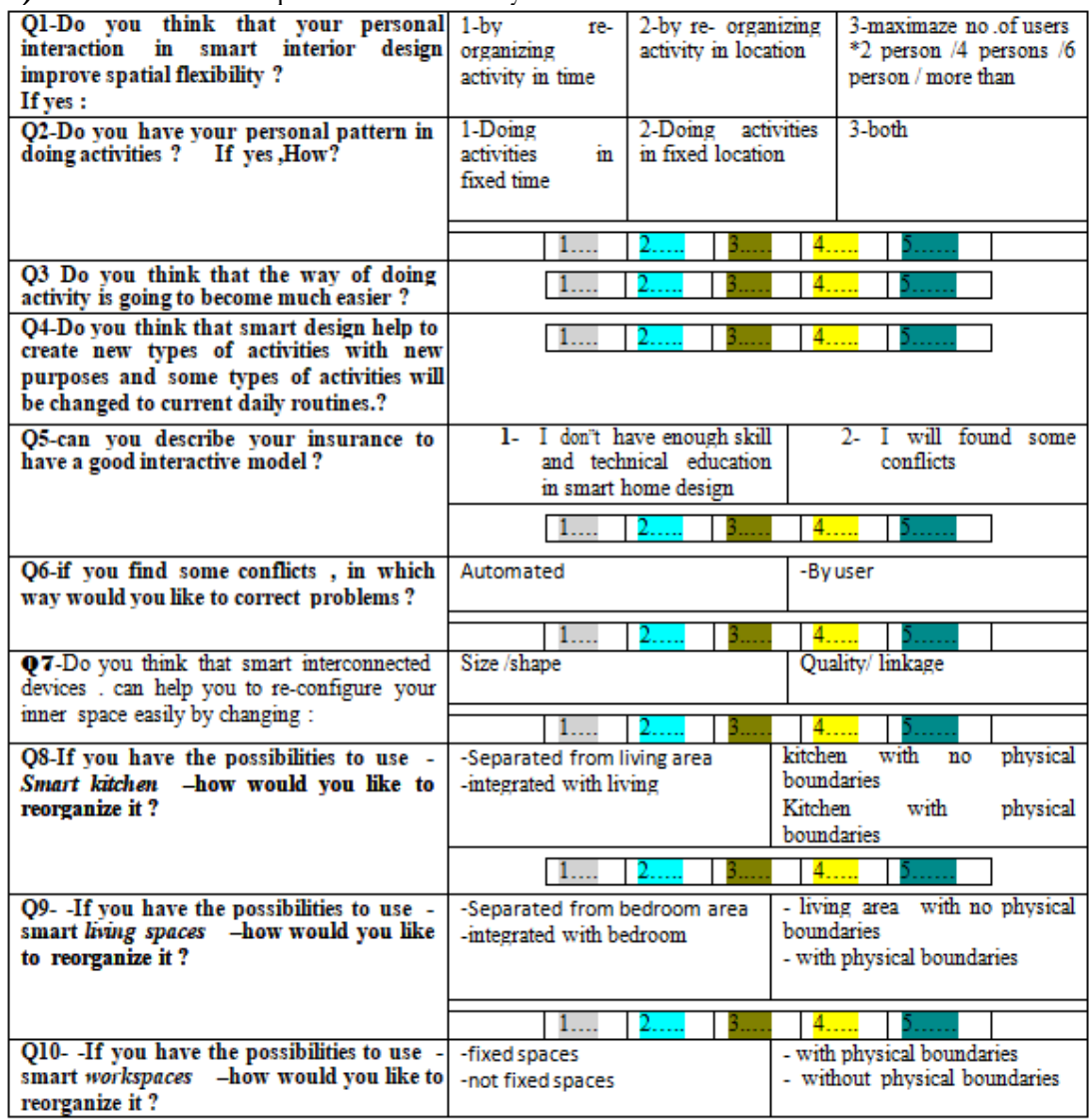

\begin{tabular}{|c|c|c|}
\hline & $2 \ldots \ldots$ & $4 \ldots \ldots$ \\
\hline \multirow{2}{*}{$\begin{array}{l}\text { Qll-If you have the possibilities to use - } \\
\text { Smart wall -in which space would you like } \\
\text { to locate it? }\end{array}$} & -Central location & -not central \\
\hline & $1 \ldots$. & $4 \ldots \ldots$ \\
\hline \multirow{2}{*}{$\begin{array}{l}\text { Q12-If you have the possibilities to use - } \\
\text { Smart boundaries-how would you like to } \\
\text { use? }\end{array}$} & \multicolumn{2}{|r|}{ with physical boundaries } \\
\hline & \begin{tabular}{|l}
$1 \ldots$ \\
\end{tabular} & \begin{tabular}{|l|l|l|} 
& $4 \ldots \ldots$ & $5 \ldots \ldots$ \\
\end{tabular} \\
\hline
\end{tabular}

Choosing shambles: Smart homes can be categorized into the following hierarchical classes table (9), [3]. In table (10) we insert different samples that we chose for applying case study. 
Table (9) Class of Smart homes -by researchers

\begin{tabular}{|l|l|l|}
\hline Class & Description & references \\
\hline $\begin{array}{l}\text { Homes, which contain single, } \\
\text { standalone intelligent objects }\end{array}$ & such as the smart kitchen table or screen fridge & Heidari Jozam, \\
intelligent objects & $\begin{array}{l}\text { M. 2017, } \\
\text { that are able to exchange information amongst one } \\
\text { another }\end{array}$ & \\
\hline Connected homes & $\begin{array}{l}\text { which have internal and external networks allowing } \\
\text { for interactive and remote control of systems. }\end{array}$ & \\
\hline Learning homes & $\begin{array}{l}\text { which use recorded and accumulated data to anticipate } \\
\text { on peoplees needs and to control the ology. }\end{array}$ & \\
\hline Responsive homes & $\begin{array}{l}\text { where people s patterns of behavior are registered and } \\
\text { used to anticipate their needs and react accordingly }\end{array}$ & \\
\hline
\end{tabular}

Table (10) Samples for applying case study -by researchers

\begin{tabular}{l|l}
$\begin{array}{l}\text { Project name } \\
\text { Danishhome } \\
\text { office furniture }\end{array}$ \\
$\begin{array}{l}\text { Reference } \\
\text { Erfaneh } \\
\text { Allameh } \\
2017 \text { p 13 }\end{array}$ \\
\cline { 2 - 4 } $\begin{array}{l}\text { Project name } \\
\text { com HOME } \\
\text { Reference } \\
\text { Erfaneh } \\
\text { Allameh, } \\
\text { P 12 }\end{array}$
\end{tabular}




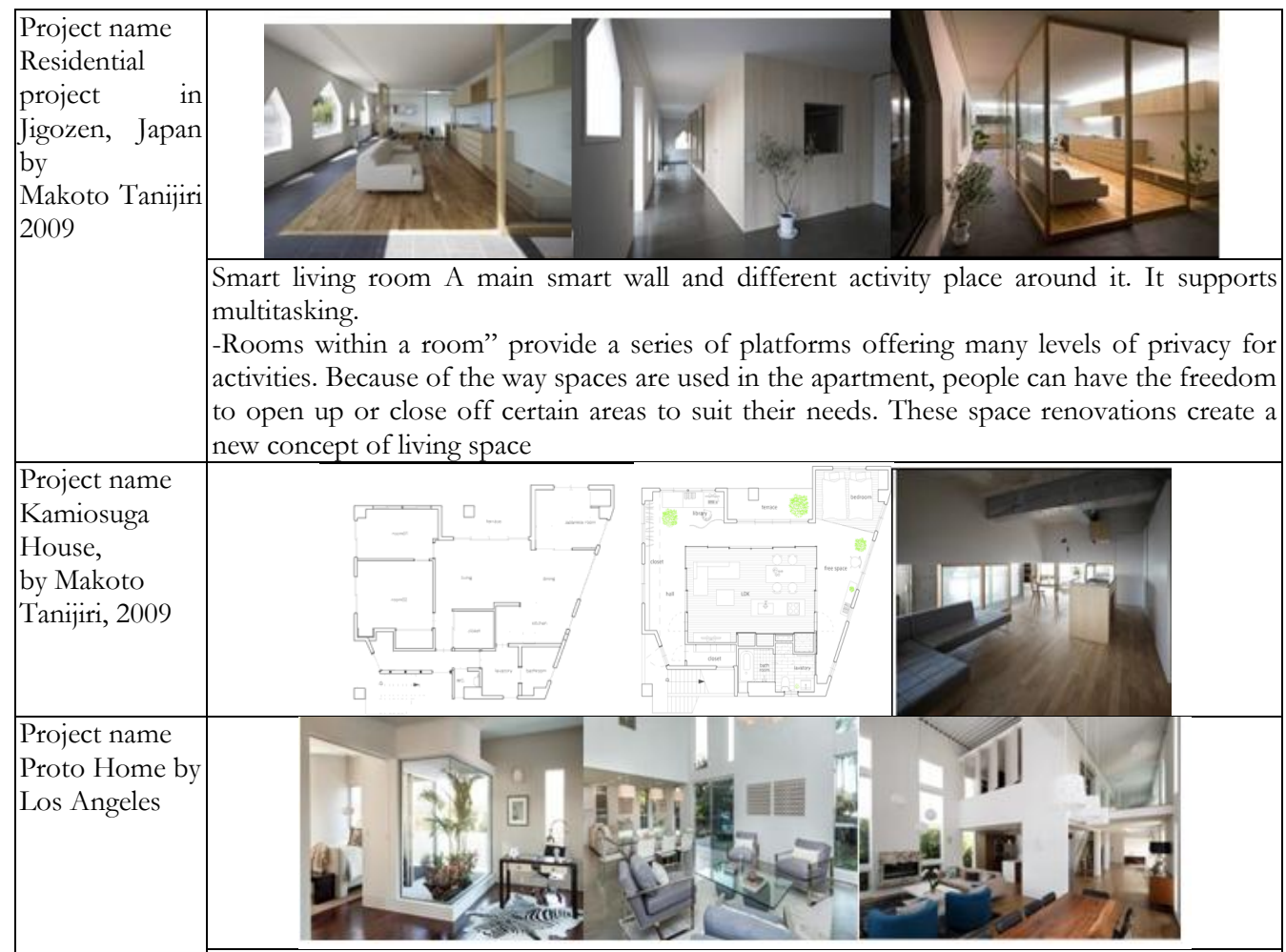

A house that accommodates your ever-changing needs. While the smart wall is central, other zones provide continuous feeling of open space. Activities are done around the smart wall while they have privacy https://www.google.com/search?q=Proto + Home + by + Los + Angeles\&source $=$ lnms\&tbm $=$ isch\&sa $=$ X\&ved $=0$ ahUKEwjTm9z2qfbiAhWJ6aYKHVaeA2cQ_AUIECgB\&biw $=1350$ $\& \mathrm{bih}=587 \#$ imgrc $=$

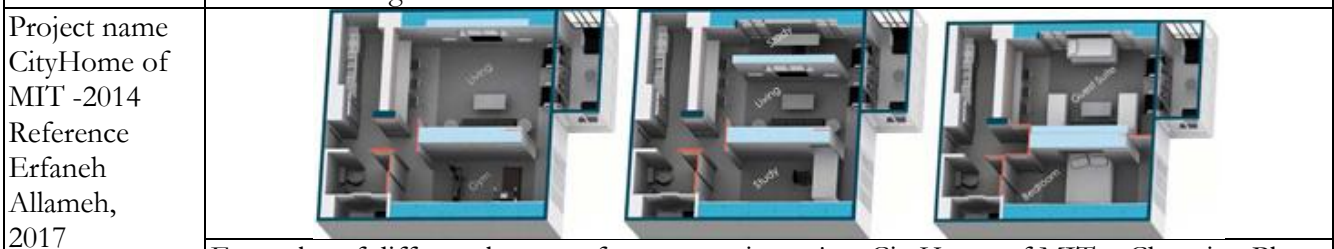
2017

Examples of different layouts of apartment in project CityHome of MIT . Changing Places Group (MIT, 2014).

\begin{tabular}{|c|c|}
\hline \multirow{2}{*}{$\begin{array}{l}\text { Project name } \\
\text { virtual design } \\
\text { of } 125 \mathrm{~m} 2 \text { \& } \\
80 \quad \mathrm{~m} 2 \text { smart } \\
\text { home - } \\
\text { Reference } \\
\text { Hederi } 2017 \\
\text { P69 }\end{array}$} & \\
\hline & $\begin{array}{l}\text { new spatial characteristics of smart homes based on users" preferences. The model is based } \\
\text { on the assumption that different individuals and households have different spatial } \\
\text { preferences due to having various characteristics, lifestyles, and needs. The notion of user } \\
\text { preference is a representation of underlying judgments of users in a decision-making process } \\
\text { of design. }\end{array}$ \\
\hline
\end{tabular}


Table 11. Results of case study -by researchers

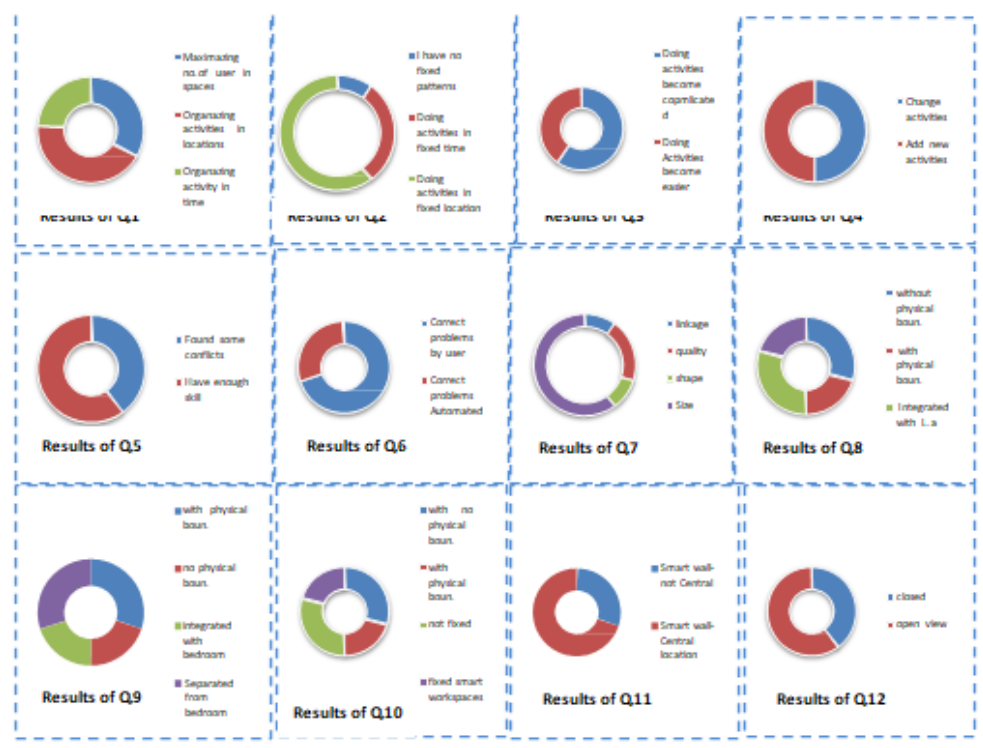

\section{Results and Conclusion}

Results in table (11) explained that:

Around $79 \%$ of Iraqis own their houses (Central Statistical Organization, 2014a, Central Statistical Organization, 2014b, The World Bank, 2011). The Iraqi National Housing Policy was updated in 2017 advocating for a new approach to manage the housing sector by develop new innovative architectural solutions with considering satisfying people preferences and providing efficient housing production. From analyzing results of case study we found that:

1-Spatial preferences: Providing sufficient total area /Providing sufficient rooms/ Providing flexibility and adaptability.

2-Social \& Psychological preferences: Providing privacy \& Providing aesthetic inner spaces. From previous literature review and from case study we are agree with results of researcher Erfaneh Allameh, 2017 -which has recognized three main areas that are mostly influenced by new technologies in a Smart Home (smart living spaces, smart kitchen and smart workplace). These three areas could be configure future Islamic smart home. Kitchen is recognized as an important place(as in traditional home) for family gathering as well as for cooking. Families want the kitchen table to be large enough to serve as a multi- purpose location. It not only helps to save space, but it also makes the kitchen environment more social and friendly. Instead of specifying one room as a kitchen(in traditional home), here, smart home concepts try to introduce a kitchen free from a room with no physical boundaries that can support multitasking activities such as virtual activities, social communication, entertainment, job_ related activities and family gatherings. Smart living rooms with smart walls should allow many activities at the same time or at different times. Both interactive and passive activities are supported by the Smart Walls, including watching TV, children gaming, Tele educating, Tele working, Tele communicating and 
surfing on internet. These new interactive aspects influence the location of the smart walls, the arrangement of the furniture around it and the entire space. Personal zones and wellness zones and their relation with public parts of a house are another important issue in studies of the spatial organization of future Smart Homes, instead of conceiving a house as a series of rooms dedicated to single functions, it is more useful to think of it as a collection of multifunctional places in which the various daily activities of household can occur. The results of the survey suggested that people also need a bedroom as a private zone beyond the purpose of sleeping.

3-Relationship between private and public zones com to be changed . Integration between workplace and living space in the Smart Home is affecting the boundaries between theme, here, the most important advantage is that people do not need a specific space to make it work. Any corner in house may be suitable as a home office thanks to ICT and AmI technologies. Due to these changes, an architecturally distinct area is no longer required and the separation of work space and living space is increasingly broken down and rearranged by "blurring boundaries. Smart technology has brought profound changes to the ways people live and work at home, without boundary less physical spaces, more virtual workspaces, and the potential for constant wireless connection to one's work. The workplace is no longer necessarily a discrete physical location.

4-Sustainability, here, is suggested to be improved by saving space and the capacity of inner spaces and smart systems to response in real time to unpredictable changes of activities and number of occupants.

5- There is a fundamental change in relationship between activities and inner spaces they -occupy -the amount and type of space that is used by given activities and this give extremely large resources and sustainability implications. This new patterns of use call for innovative and sustainable activity-space planning

\section{References}

Ajla Aksamija, Integrating Innovation In Architecture, Design, Methods And Technology For Progressive Practice And Research p. 12-17, 2016.

Abdulpader, QADER., Sabah, O. A. , \& Abdullah, H. S, Impact of flexibility principle on the efficiency of interior design. International Transaction Journal of Engineering, Management, \& Applied Sciences \& Technologies, p 195-212, p202, 2014.

Art of service-p9-14, , 2018,

Branko Kolarevic and Vera Parlac, Building dynamics-Exploring architecture of changes, Published by Routledge, London and New York, p. 51, p9, p45-57, p52, p53, p37, 2015.

Del Nord, Romano, Hospital Planning, Published by TESIS Inter University Research center, University of Florence, Italy, p66, , 2012

Estaji, H. , A review of Flexibility and Adaptability in Housing Design. International Journal of Contemporary Architecture" The New ARCH", pp. 38, 2017

Erfaneh Allameh, Mohammadali Heidari Jozam, Bauke de Vries, Harry Timmermans and Jakob Beetz, Smart Home as a smart real estate A state of the art review, Architecture, Building and Planning Department, Eindhoven University of Technology, P. O. Box 513, 5600 MB, Eindhoven, the Netherlands, p14-16, 2011,

FaizaNakib, -Technological Adaptability, an Approach Towards a Flexible AND Sustainable Architecture, Éco le Polytechniqued' architecture et d'urbanism (EPAU), Conference Paper ·p2-4, 2010 
Graham, P. , Design for adaptability - an introduction to the principles and basic strategies. The Royal Australian Institute of Architects, . GEN66. p7, 2005.

Ghaffarian Hoseini, A. , Creating green culturally responsive intelligent buildings: Socio-cultural and environmental influences. Intelligent Buildings International, 3(1), pp. 5-23, 2011.

Heidari Jozam, M. Smart home design: spatial preference modeling of smart homes, p26, 2016

Haile LI - Versatile Space: The Trend to Multi-functional Space And Design Strategy, Department of Architecture-Chongqing University, Chongqing, p. 69, p30- p36, P72, 2005.

Kang, M. \& Guerin, D. A. , The state of environmentally sustainable interior design practice. American Journal of Environmental Sciences. 5(2), pp. 179-186, 2009.

Maad Bali, Dietmar A. Half, Dieter Polle, Jurgen Spitz), Smart building design, conception, planning, realization and operation $\mathrm{p} 24, \mathrm{p} 70-74,2018$.

Newman, P. , The Environmental Impact of Cities, Environment and Urbanization, 18(2), p. 275 -295, 2006.

Ruff, C. L. , \& Olson, M. A. (2009). The attitudes of interior design students towards sustainability. International Journal of Technology and Design Education. 19(1), 67-77. doi: 10. 1007/s10798007-9038-0

Stephen Grabow, The Architecture of Use, Aesthetic and function in architecture, New york and London, printed in Great Britain, 2015

Sassi, P. , Strategies for sustainable architecture, Taylor and Francis: New York, 2006.

William Fawcett, Activity -space research (built space I the digital world), published through great space independent publishing platform, p. 48, p46, UK 2016,

W. Rashdan, The impact of innovative smart design, solutions on achieving sustainable interior design College of Design, Al Ghurair University, UAE, This paper is part of the Proceedings of the 11 International th Conference on Urban Regeneration and Sustainability (SC 2016) www. witconferences. com, p. 628, p623, 2016 